\title{
3D Geometrical Solutions for Toroidal LPG Fuel Tanks Used in Automotive Industry
}

\author{
Mihai Țălu ${ }^{1}$ and Ştefan Ţălu ${ }^{2, *}$ \\ ${ }^{1}$ University of Craiova, Faculty of Mechanics, Department of Applied Mechanics and Civil Engineering, Calea București Street, \\ no. 107, Craiova, 200512, Dolj county, Romania \\ ${ }^{2}$ The Technical University of Cluj-Napoca, The Directorate of Research, Development and Innovation Management (DMCDI), \\ Constantin Daicoviciu Street, no. 15, Cluj-Napoca, 400020, Cluj county, Romania \\ ${ }^{*}$ Corresponding author
}

\begin{abstract}
This study aims to investigate various geometrical solutions of toroidal LPG (Liquefied Petroleum Gas) fuel tanks used in automotive industry, using CAD parametric modeling. The CAD modeling has a potential impact required to develop and to implement new mathematical models on the engineering design process of toroidal LPG fuel tanks.
\end{abstract}

Keywords - automotive industry; geometrical models; industrial engineering design; optimization methods; toroidal LPG fuel tank

\section{INTRODUCTION}

During the last few decades, in parallel to the formation of global market structures, the business strategies in automotive industry imposed global-scale patterns of integration, but it has also developed strong regional-scale patterns of integration improving vehicle design/engineering [1-4].

Key structural features of both car production and sales differ for every vehicle model and require particularization because of the high level of inter-relationships in the performance characteristics of components [4].

On the other hand, in automotive sector, instruments of regional industrial policy, standards and industry regulations, necessitate local adaptations, local models, local production, and local innovation activities to satisfy local needs [2-4].

Significant contributions has been made in automotive industry by vehicle architects, design engineers and project managers in terms of technology, techniques and material to improve many aspects such as safety, reliability and technology of car at a high level to meet the customer needs and expectations $[1,2]$.

In order to achieve these targets (the customer attributes and technical specification) the designed vehicles are adapted for local markets, and there are used various practices in design and manufacturing for increased productivity, low design cost, low production cost and improved quality control [2-4].

The first CAD systems began to appear out of research and into commercial use in automotive industry in the 1980s [5-9].

CAD systems (with the use of parametric modeling) improve the quality of design (conceptual, embodiement and detail design), increase the productivity of the designer, reduce time-consuming build-test-redesign iterations, improve communications between all phases through documentation, and create a database for manufacturing [5-9].

In modern $\mathrm{CAD}$ sophisticated software's (combining 3D surface/solid computer modeling, animation and powerful computers) for creating complex computer adaptable models of the car concept or detailed geometrical design [10, 11], algorithms act in complex patterns and automated programmable interfaces that have demonstrated to be vital in vehicle manufacturing process [12-17].

3D-CAD models include product-specific features and flexible tools that link a library of 3D shapes, the geometry of parts, additional constraint information, with their functions in diagrammatic visualization of qualitative information necessary for various simulation, verification and validation processes [59].

Storage fuel tanks used in automotive industry contain technologically advanced components [18-21] and their design takes into account the supershapes design variables [22-24], specific structural parameters [25-27], precise geometrical conditions of linkage structural parameters [28, 29], computer tools [5-9], numerical computational algorithms and methods [30-32], visualization techniques [33-39], generative design and verification conditions [40, 41].

Liquefied petroleum gas (LPG) describes flammable hydrocarbon gases including propane, butane and mixtures of these gases used as fuel in vehicles [42].

In comparison with to fuels like petrol and diesel, LPG has its advantages and disadvantages in next aspects: environmental impact; efficiency and performance; availability; safety; and financial requirements and costs [43].

LPG is considered clean, safe and cheap, offering a viable alternative to conventional fuels [44].

A toroidal storage tank is a complex geometrical product that can be considered as a shell in the form of the surface of revolution with the wall thickness very small in comparison with its other dimensions [45].

The most important mechanical properties toroidal LPG tanks in designing process are the following: the static behavior under internal pressure, the vibration characteristics, the 
buckling and collapse loads, and the properties under impact loading arising from accident conditions [45].

The toroidal LPG fuel tanks (usually made of thick steel) can be placed in various locations in function of amount of space available, vertically or horizontally. The majority of vehicles have the tank installed in place of the spare tyre, and can be mounted (as shown in figure 1) [46-48].

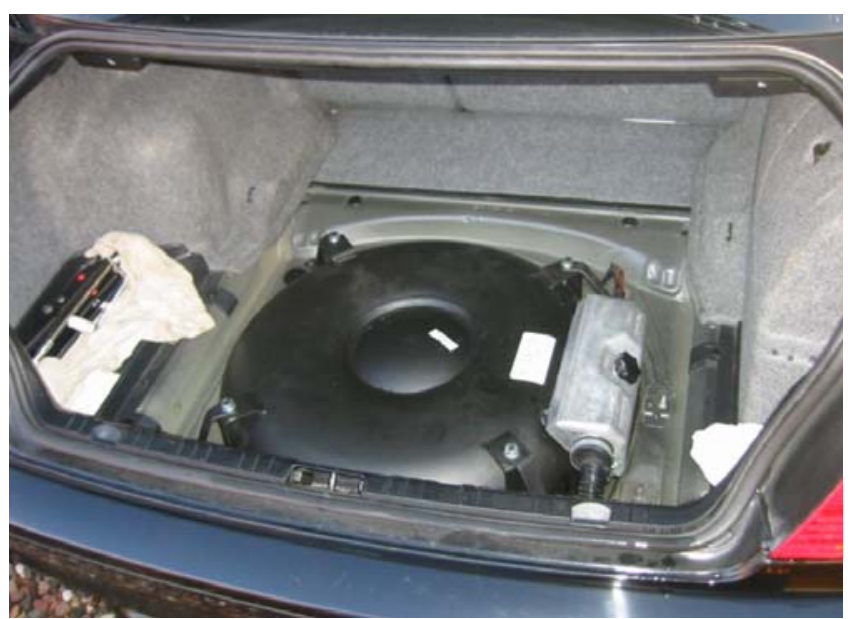

a) LPG installed instead of spare wheel inside
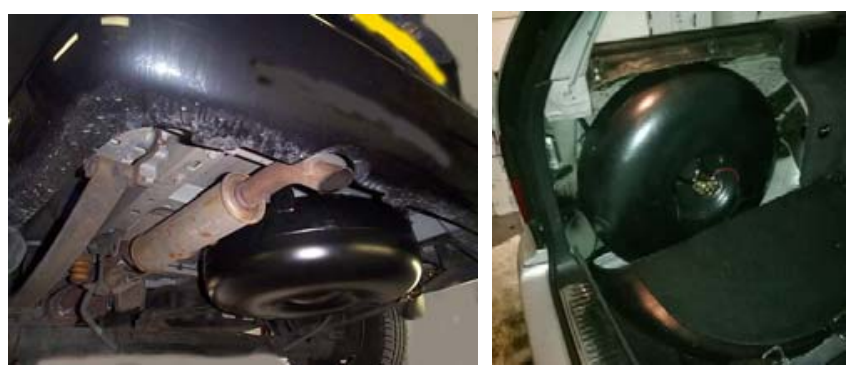

b) LPG installed outside

b) LPG installed in left side

FIGURE I. EXAMPLE OF TOROIDAL LPG FUEL TANK INSTALLATION

In this study, various CAD solutions of toroidal LPG fuel tanks (figure 2) used in automotive industry are proposed.

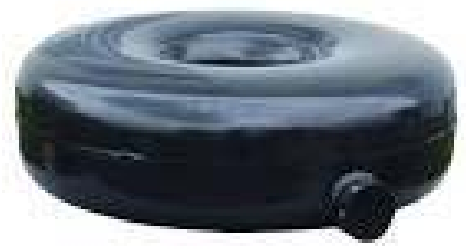

FIGURE II. STANDARD SHAPE OF TOROIDAL LPG FUEL TANK

\section{Design Methodology}

The toroidal surfaces are graphically represented in figure 3 by applying parametric 3D modeling using different mathematical equations.

\section{A. Piriform Curve}

The Piriform curve (figure 3a) is given by the Cartesian equation [49]:

$$
a^{4} y^{2}=b^{2} x^{3}(2 a-x)
$$

The area of the piriform curve is:

$$
\mathrm{A}=\pi \mathrm{ab} .
$$
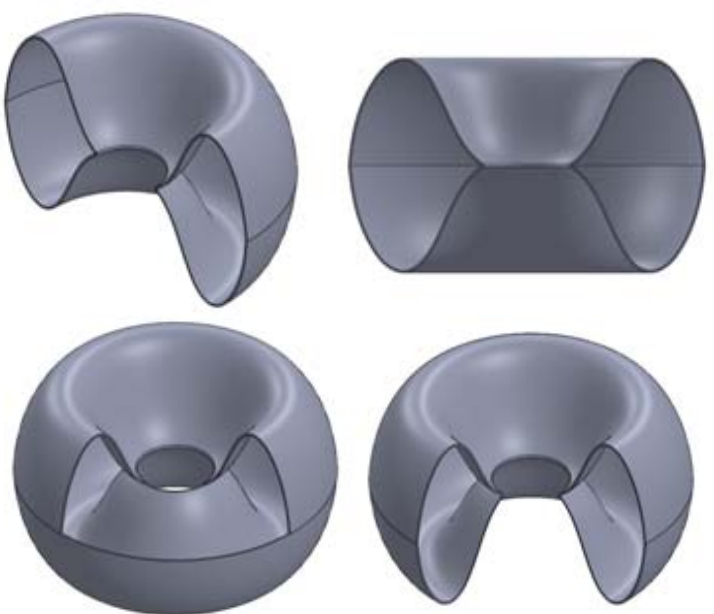

a1)
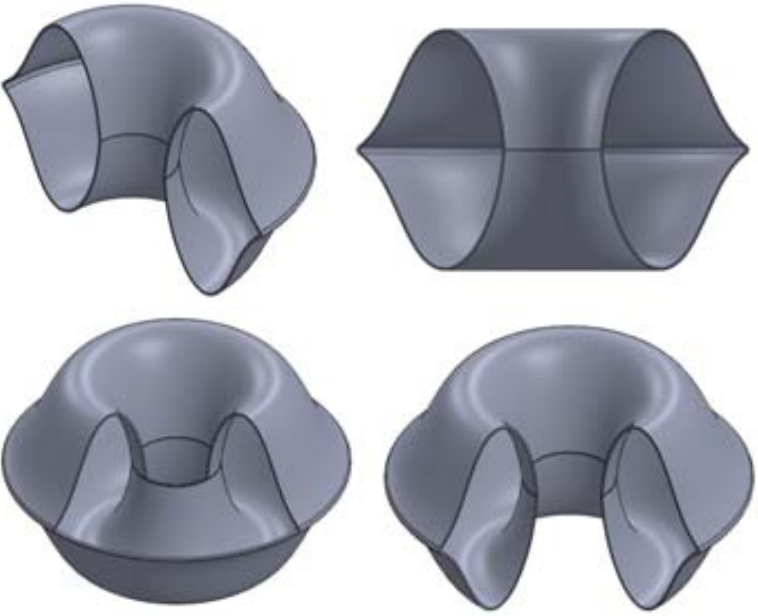

a2)

\section{B. Burnside curve}

The Burnside curve (figure $3 b$ ) is given by the Cartesian equation [49]:

$$
y^{2}-x\left(x^{4}-1\right)=0
$$

The closed portion of the curve has area: 


$$
A=\frac{\sqrt{\pi} \Gamma\left(\frac{3}{8}\right)}{4 \Gamma\left(\frac{15}{8}\right)}
$$

where $\Gamma(\mathrm{z})$ is a gamma function.
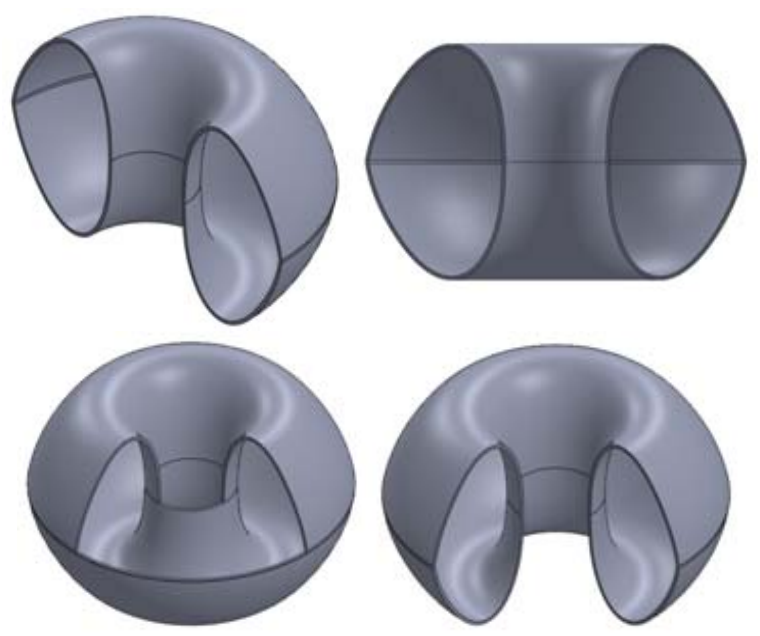

b1)
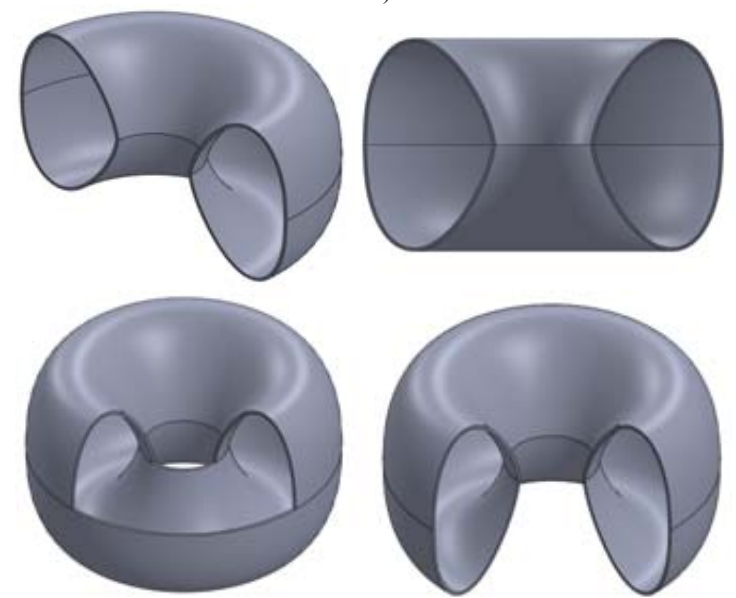

b2)

\section{Curve of Degree 6}

The epicycloid (figure 3c) is given by the parametric equations [49]:

$$
\begin{aligned}
& x=(a+b) \cos \phi-b \cos \left(\frac{a+b}{b} \phi\right) \\
& y=(a+b) \sin \phi-b \sin \left(\frac{a+b}{b} \phi\right) .
\end{aligned}
$$
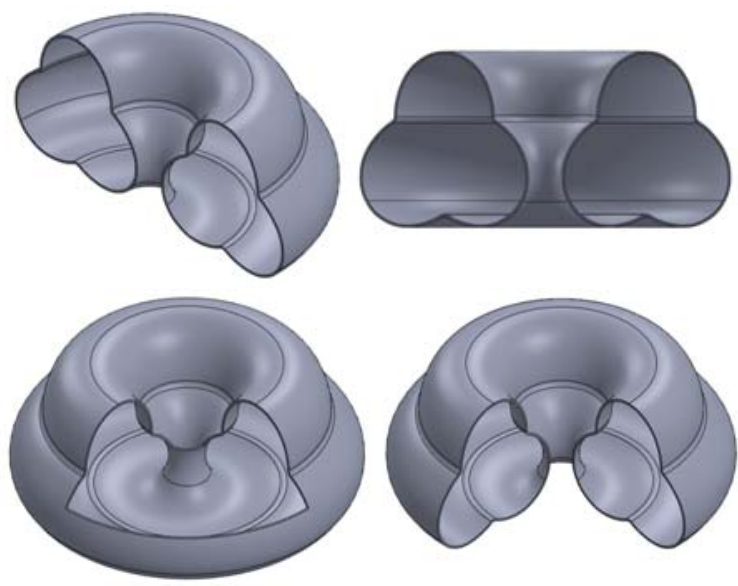

c1)
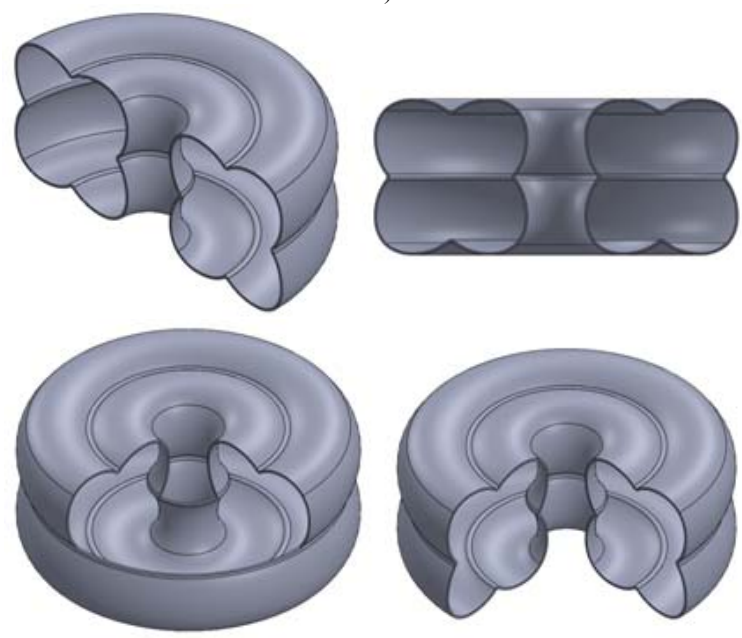

c2)

\section{Nephroid}

The nephroid (figure 3d) is a 2-cusped epicycloid given by Cartesian equation [49]:

$$
\left(x^{2}+y^{2}-4 a^{2}\right)^{3}=108 a^{4} y^{2} .
$$

The nephroid has area:

$$
A=12 \pi a^{2}
$$

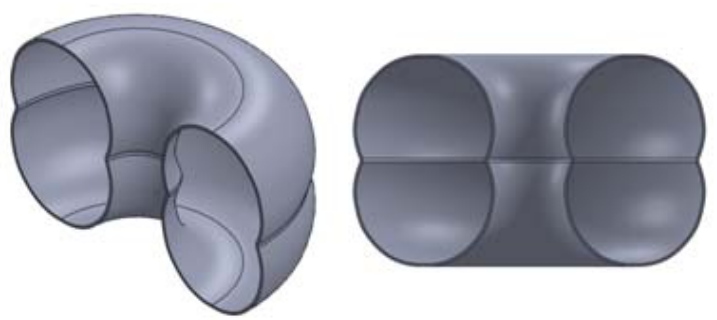



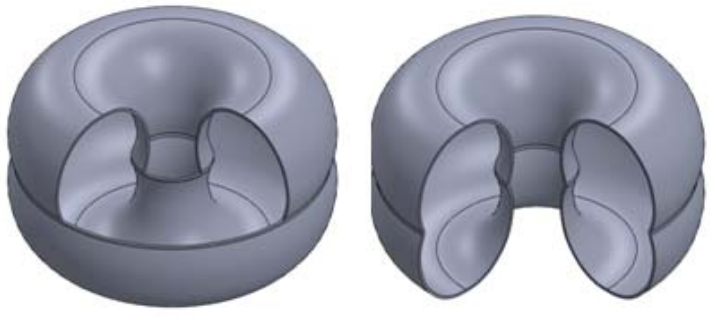

d)

\section{E. Pear Curve}

The pear curve (figure 3e) in Cartesian coordinates with a constant $r$ is given by the equation [49]:

$$
\begin{array}{r}
r^{2}=\left(x^{2}+y^{2}\right)\left(1+2 x+5 x^{2}+6 x^{3}+6 x^{4}+4 x^{5}+x^{6}-3 y^{2}-2 x y^{2}+\right. \\
\left.+8 x^{2} y^{2}+8 x^{3} y^{2}+3 x^{4} y^{2}+2 y^{4}+4 x y^{4}+3 x^{2} y^{4}+y^{6}\right) .
\end{array}
$$
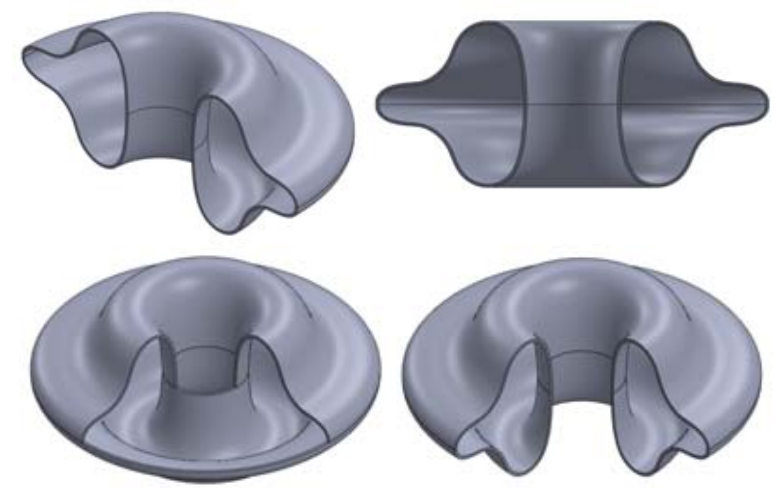

e)

\section{F. Ranunculoid Curve}

The Ranunculoid curve (figure $3 f$ ) is given by the parametric equations [49]:

$$
\begin{aligned}
& x=a[6 \cos t-\cos (6 t)] \\
& y=a[6 \sin t-\sin (6 t)] .
\end{aligned}
$$

The area is given by relation:

$$
A=42 \pi a^{2}
$$

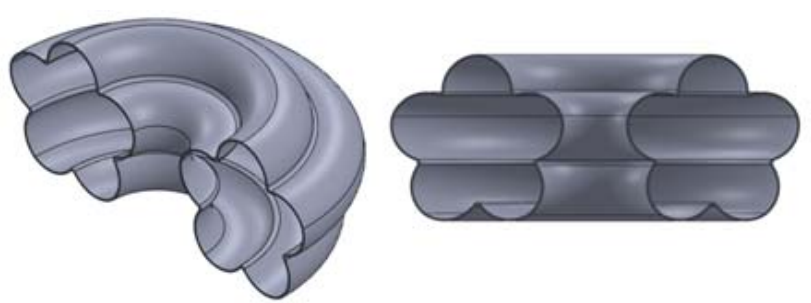

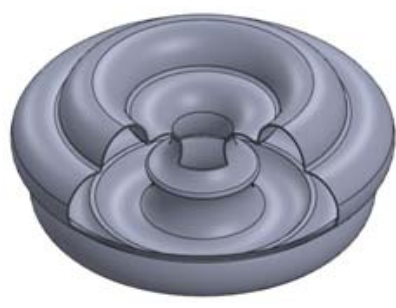

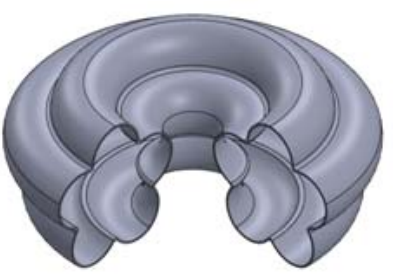

f)

FIGURE III. EXAMPLE OF 3D MODELING OF THE PARTICULAR TOROIDAL SURFACES

\section{CONCLUSIONS}

In this study the 3-D solid modeling were applied to find different solutions of toroidal LPG fuel tanks used in automotive industry.

3D geometric models, that include geometric conventional shapes as well as other less traditional shapes, can be used in geometric design for more comprehensive design and analysis.

The specific shape of these 3D models of toroidal LPG fuel tank can provides different opportunities and advantages and can be used for optimal engineering design process in various applications by engineers and researchers.

\section{REFERENCES}

[1] M. Hirz, P. Rossbacher, and J. Gulanová, "Future trends in CAD - from the perspective of automotive industry," Computer-Aided Design and Applications, vol. 14, iss. 6, pp. 734-741, 2017.

[2] T.J. Sturgeon, O. Memedovic, J. Van Biesebroeck, and G. Gereffi, "Globalisation of the automotive industry: main features and trends," Int. J. Technological Learning, Innovation and Development, vol. 2, nos. 1/2, pp. 7-24, 2009.

[3] P. Padagannavar, "Automotive product design and development of car dashboard using quality function deployment. Adv. Automob. Eng., vol. 5. iss. 1, pp. 136, 2016. doi: 10.4172/2167-7670.1000136.

[4] M. Gastrow, "A review of trends in the global automotive manufacturing industry and implications for developing countries," Afr. J. Bus. Manag., vol. 6, iss. 19, pp. 5895-5905, 2012. doi: 10.5897/AJBM12.087.

[5] Ş. Țălu, Computer assisted technical graphics. Cluj-Napoca, Romania: Victor Melenti Publishing house, 2001.

[6] Ş. Ţălu, Computer assisted graphical representations. Cluj-Napoca, Romania: Osama Publishing house, 2001.

[7] Ş. Ţălu, AutoCAD 2005. Cluj-Napoca, Romania: Risoprint Publishing house, 2005.

[8] Ş. Ţălu and M. Ţălu, AutoCAD 2006. Three-dimensional designing. Cluj-Napoca, Romania: MEGA Publishing house, 2007.

[9] Ş. Ţălu, AutoCAD 2017. Cluj-Napoca, Romania: Napoca Star Publishing house, 2017.

[10] V.J. Venkanna, S.J. Singh, A.Vijaykanth, and K.A. Kumar, "Analysis of automobile LPG cylinder using composite material," International Journal of Mechanical And Production Engineering, vol. 2, iss. 5, pp. 29-32, 2014.

[11] Ş. Ţălu, AutoLISP programming language. Theory and applications. Cluj-Napoca, Romania: Risoprint Publishing house, 2001.

[12] M.C. Ghiţă, A.C. Micu, M. Țălu, and Ş. Țălu, "Shape optimization of vehicle's methane gas tank," Annals of Faculty of Engineering Hunedoara - International Journal of Engineering, Hunedoara, Tome X, Fascicule 3, pp. 259-266, 2012.

[13] M.C. Ghiță, A.C. Micu, M. Țălu, Ş. Țălu, and E. Adam, "Computer-Aided Design of a classical cylinder gas tank for the automotive industry," 
Annals of Faculty of Engineering Hunedoara - International Journal of Engineering, Hunedoara, Tome XI, Fascicule 4, pp. 59-64, 2013.

[14] M.C. Ghiță, A.C. Micu, M. Țălu, and Ş. Țălu, "3D modelling of a gas tank with reversed end up covers for automotive industry,", Annals of Faculty of Engineering Hunedoara - International Journal of Engineering, Hunedoara, Tome XI, Fascicule 3, pp. 195-200, 2013.

[15] M.C. Ghiţă, A.C. Micu, M. Țălu, and Ş. Țălu, "3D modelling of a shrink fitted concave ended cylindrical tank for automotive industry," Acta Technica Corviniensis - Bulletin of Engineering, Hunedoara, Romania, Tome VI, Fascicule 4, pp. 87-92, 2013.

[16] M.C. Ghiță, A.C. Micu, M. Tălu, and S. Tălu, "Shape optimization of a thoroidal methane gas tank for automotive industry," Annals of Faculty of Engineering Hunedoara - International Journal of Engineering, Hunedoara, Tome X, Fascicule 3, pp. 295-297, 2012.

[17] M.C. Ghiță, C.Ș. Ghiță, S. Țălu, and S. Rotaru, "Optimal design of cylindrical rings used for the shrinkage of vehicle tanks for compressed natural gas," Annals of Faculty of Engineering Hunedoara - International Journal of Engineering, Hunedoara, Tome XII, Fascicule 3, pp. 243-250, 2014.

[18] M. Bică, M. Țălu, and Ș. Țălu, "Optimal shapes of the cylindrical pressurized fuel tanks," Magazine of Hydraulics, Pneumatics, Tribology, Ecology, Sensorics, Mechatronics (HIDRAULICA), no. 4, pp. 6-17, 2017.

[19] Ș. Țălu, and M. Țălu, "The influence of deviation from circularity on the stress of a pressurized fuel cylindrical tank," Magazine of Hydraulics, Pneumatics, Tribology, Ecology, Sensorics, Mechatronics (HIDRAULICA), no. 4, pp. 34-45, 2017.

[20] D. Vintilă, M. Țălu, and Ș. Țălu, "The CAD analyses of a torospheric head cover of a pressurized cylindrical fuel tank after the crash test," Magazine of Hydraulics, Pneumatics, Tribology, Ecology, Sensorics, Mechatronics (HIDRAULICA), no. 4, pp. 57-66, 2017.

[21] M. Tălu, "The influence of the corrosion and temperature on the Von Mises stress in the lateral cover of a pressurized fuel tank," Magazine of Hydraulics, Pneumatics, Tribology, Ecology, Sensorics, Mechatronics (HIDRAULICA), no. 4, pp. 89-97, 2017.

[22] Ș. Ţălu, and M. Ţălu, "A CAD study on generating of 2D supershapes in different coordinate systems," Annals of Faculty of Engineering Hunedoara - International Journal of Engineering, Hunedoara, Tome VIII, Fascicule 3, pp. 201-203, 2010.

[23] Ş. Ţălu, and M. Țălu, "CAD generating of 3D supershapes in different coordinate systems," Annals of Faculty of Engineering Hunedoara International Journal of Engineering, Hunedoara, Tome VIII, Fascicule 3, pp. 215-219, 2010.

[24] Ş. Țălu,, "CAD representations of 3D shapes with superellipsoids and convex polyhedrons," Annals of Faculty of Engineering Hunedoara International Journal of Engineering, Hunedoara, Tome IX, Fasc. 3, pp. 349-352, 2011

[25] M. Tălu, and S. Tălu, "Analysis of temperature resistance of pressurized cylindrical fuel tanks," Magazine of Hydraulics, Pneumatics, Tribology, Ecology, Sensorics, Mechatronics (HIDRAULICA), no. 1, pp. 6-15, 2018.

[26] M. Țălu, and Ş. Țălu, "Design and optimization of pressurized toroidal LPG fuel tanks with variable section," Magazine of Hydraulics, Pneumatics, Tribology, Ecology, Sensorics, Mechatronics (HIDRAULICA), no. 1, 2018, in press.

[27] S. Tălu, and M. Tălu, "Algorithm for optimal design of pressurized toroidal LPG fuel tanks with variable section described by imposed algebraic plane curves," Magazine of Hydraulics, Pneumatics, Tribology, Ecology, Sensorics, Mechatronics (HIDRAULICA), no. 1, 2018, in press.

[28] M. Țălu, and Ş. Țălu,, "Numerical analysis of cylindrical fuel tanks thermal behaviour," Annals of Faculty of Engineering Hunedoara International Journal of Engineering, Hunedoara, 2018, in press.

[29] [39] M. Tălu, and S. Tălu, "Optimal engineering design of a pressurized paralepipedic fuel tank," Annals of Faculty of Engineering Hunedoara - International Journal of Engineering, Hunedoara, 2018, in press.

[30] M. Țălu. Calculation of distributed pressure loss in hydraulic pipelines. Craiova, Romania: Universitaria Publishing house, 2016.

[31] M. Ţălu, Fluid mechanics. The monodimensional laminar flow. Craiova, Romania: Universitaria Publishing house, 2016.
[32] M. Țălu. Hydraulic pressure loss in technical piping with annular section Numerical calculation and C.F.D. Craiova, Romania: Universitaria Publishing house, 2016.

[33] G.V. García, and S. Tălu, "Dihedrical angle between two oblique planes line of intersection not given using the Valencia \& Țălu method," Annals of Faculty of Engineering Hunedoara - International Journal of Engineering, Hunedoara, Tome XV, Fascicule 1, pp. 131-134, 2017.

[34] Ş. Tălu, Descriptive geometry. Cluj-Napoca, Romania: Risoprint Publishing house, 2010.

[35] A. Florescu-Gligore, M. Orban and Ş. Ţălu, Dimensioning in technological and constructive engineering graphics. Cluj-Napoca, Romania: Lithography of Technical University of Cluj-Napoca, 1998.

[36] A. Florescu-Gligore, Ș. Tălu and D. Noveanu, Representation and visualization of geometric shapes in industrial drawing. Cluj-Napoca, Romania: U. T. Pres Publishing house, 2006.

[37] T. Niţulescu and Ș. Ţălu, Applications of descriptive geometry and computer aided design in engineering graphics. Cluj-Napoca, Romania: Risoprint Publishing house, 2001.

[38] C. Racocea and Ș. Ţălu, The axonometric representation of technical geometric shapes, Cluj-Napoca, Romania: Napoca Star Publishing house, 2011.

[39] Ș. Țălu and C. Racocea, Axonometric representations with applications in technique. Cluj-Napoca, Romania: MEGA Publishing house, 2007.

[40] C. Bîrleanu and Ş. Ţălu, Machine elements. Designing and computer assisted graphical representations. Cluj-Napoca, Romania: Victor Melenti Publishing house, 2001.

[41] Ş. Tălu, Micro and nanoscale characterization of three dimensional surfaces. Basics and applications. Cluj-Napoca, Romania: Napoca Star Publishing House, 2015.

[42] http://www.elgas.com.au

[43] E. Liu, S.Y. Yue, and J. Lee, "A study on LPG as a fuel for vehicles," 1997. http://www.legco.gov.hk/yr97-98/english/sec/library/967rp05.pdf

[44] H. Zhan, Master thesis: Static and Dynamic Analysis of Toroidal LPG Tanks, University of Ottawa, Canada, 2008.

[45] V. Veličković, "Stress and Strain States in the Material of the Stressed Toroidal Container for Liquefied Petroleum Gas," Scientific Technical Review, vol.LVII, no.3-4, 2007, pp. 94-105.

[46] http://www.lpgain.com/tank-sizes.html

[47] http://www.lpg-car-conversion-london.com/

[48] http://dbsouthtrade.ro/en/external-toroidal-tanks

[49] http://mathworld.wolfram.com. 